\title{
硫黄脱窒菌の集積と単体硫黄への馴養
}

橋 本 奨* 古川憲治* 塩 山昌 彦*

\section{Enrichment of Sulfur Denitrifying Bacteria and its Acclimation to Elemental Sulfur}

\author{
Susumu HASHIMOTO*, Kenji FURUKAWA* and Masahiko SHIOYAMA* \\ * Department of Environmental Engineering, Faculty of Engineering, Osaka University, 2-1, Yamada-Oka, \\ Suita-shi, Osaka 565 Japan
}

\begin{abstract}
In order to utilize the denitrifying capability of sulfur denitrifying bacteria for nitrogen removal of wastewater, the preparation method of enrichment culture with high denitrification activity and the acclimation method of this enriched culture to elemental sulfur were investigated.

Isolation of Thiobacillus denitrificans was carried out in order to evaluate the denitrifying capability of $T$. denitrificans. The enrichment cultures of $T$. denitrificans were easily established from various inoculating sources, such as activated sludge and the bottom mud of polluted river, in a medium wherein $\mathrm{HCO}_{3}{ }^{-}$was used as the inorganic carbon source and $\mathrm{S}_{2} \mathrm{O}_{3}{ }^{2-}$ and $\mathrm{S}^{0}$ were used as the reduced sulfur source. Plating cultures of these enriched microorganisms were conducted and the single yellow colony, in which the deposit of sulfur particles was observed, was obtained. A pure single isolate was obtained through repeated plating cultures, and was identified as $T$. denitrificans.

The medium which was defined by $\mathrm{K}$. Baalsrud was found to be a suitable medium for the enrichment culture of sulfur denitrifier. The stoichiometric values of autotrophic sulfur denitrification reaction such as $Y_{s}, Y_{a l k}, Y_{o b}$ and $C_{R}$ for enriched microorganisms were in fair agreement with the theoretical values, so that the nitrogen removal capability of the enriched culture was proved to be mainly governed by the denitrification capability of sulfur denitrifier. The sulfur denitrifier which were acclimated to $\mathrm{S}_{2} \mathrm{O}_{3}{ }^{2-}$ could be successfully acclimated to elemental sulfur by the gradual stepwise replacement of $\mathrm{S}_{2} \mathrm{O}_{3}{ }^{2-}$ to elemental sulfur. Denitrification reaction by the enriched sulfur denitrifier followed the zero order kinetics. The specific denitrification rates of enriched microorganinsms were $9.4 \mathrm{mg}-\mathrm{N} \cdot \mathrm{mg}^{-1} \mathrm{TOC} \cdot \mathrm{d}^{-1}$ in case of $\mathrm{S}_{2}$ $\mathrm{O}_{3}{ }^{2-}$ and $2.5 \mathrm{mg}-\mathrm{N} \cdot \mathrm{mg}^{-1} \mathrm{TOC} \cdot \mathrm{d}^{-1}$ in case of $\mathrm{S}_{0}$, respectively, which were comparable with that of heterotrophic denitrifiers.
\end{abstract}

Key words: Thiobacillus denitrificans, denitrification, sulfur oxidation, enrichment culture, isolation, elemental sulfur, $\mathrm{S}_{2} \mathrm{O}_{3}{ }^{2-}$, acclimation

\section{1. 緒言}

自然界には，脱窒反応の電子供与体として有機物を 要求する他栄養脱窒菌（heterotrophic denitrifier）の
ほかに, $\mathrm{S}^{2-}, \mathrm{S}^{0}, \mathrm{~S}_{2} \mathrm{O}_{3}{ }^{2-}, \mathrm{S}_{4} \mathrm{O}_{5}{ }^{2-}, \mathrm{SO}_{3}{ }^{2-}$ などの還元 硫黄化合物を脱窒反応の電子供与体として, これを酸 化するときに発生するエネルギーを利用して生育でき る自栄養脱窒菌(autotrophic denitrifier)のThiobacillus

* 大阪大学工学部環境工学科 $\mathbf{T} 565$ 大阪府吹田市山田丘 2-1 
denitrificans が存在する。他栄養脱窒菌を利用する場 合，有機物として高価なメタノールを使用したり，污 泥循環を頻繁に行らなど，経済面で強く制約され，そ れが本法の普及を妨げている。しかし，コストの安い 粉末あるいは粒状硫黄を電子供与体とする硫黄脱窒細 菌の脱窒反応を下廃水処理に活用できれば，極めて安 価に硝化二次処理水の脱窒や，電子供与体の不足する 脱窒槽の脱窒能力の向上が図れるので, 生物学的窒素 除去法の普及が期待でき，水質污濁防止に果たす役割 は極めて大きい。しかし，硫黄脱窒細菌の脱窒反応条 件や最適生育条件など，実施設へ適用するための基礎 的知見は極めて少ない。そこで，T. denitrificans の純 粋分離を行い, 本菌の特性について検討するとともに, 自然界から硫黄脱窒能の高い混合菌を集積し, さらに 集積菌の単体硫黄 $\left(\mathrm{S}^{0}\right)$ への馴養について種々検討を加 え, 有用な知見が得られたのでその研究結果を報告す る。

\section{T. denitrificans の特性について}

\subsection{T. denitrificans の一般的性質}

T. denitrificans は，還元硫黄化合物の $\mathrm{SO}_{4}{ }^{2-}$ 一の酸 化時に, $\mathrm{NO}_{3}$-を $\mathrm{N}_{2}$ に脱窒できる胞子形成のない自栄 養性グラム陰性桿菌で, その細胞の大きさは $0.5 \times 1.0$ $\mu \mathrm{m}$ である。この細菌は, $\mathrm{O}_{2}, \mathrm{NO}_{3}^{-}, \mathrm{NO}_{2}^{-}, \mathrm{NO}, \mathrm{N}_{2}$ $\mathrm{O}$ を硫黄酸化の最終電子受容体として用い, $\mathrm{SO}_{4}{ }^{2-}$ が 最終生産物である。ただし, 本菌の生育には, 最終電 子受容体として, $\mathrm{NO}_{3}{ }^{-} よ り \mathrm{O}_{2}$ を好むが, 脱窒反応は $\mathrm{O}_{2}$ がなく, $\mathrm{NO}_{3}$-の存在するいわゆる anoxic 環境条件 でのみ起こり, 生育最適 $\mathrm{pH}$ は, 6 〜 8 の中性域にあ る。

T. denitrificans による $\mathrm{NO}_{3}$-から $\mathrm{N}_{2}$ への還元反応 は，NOを還元中間体とする次のような経路で進行す る1)。

$$
\mathrm{NO}_{3}{ }^{-} \rightarrow \mathrm{NO}_{2}{ }^{-} \rightarrow \mathrm{NO} \rightarrow \mathrm{N}_{2} \mathrm{O} \rightarrow \mathrm{N}_{2}
$$

$\mathrm{NO}_{3}$-を最終電子受容体として生育する $T$. denitrificans には, チトクローム系の電子伝達系が存在する が， $\mathrm{NO}_{3}$-の還元反応が $\mathrm{O}_{2}$ により阻害を受けることか ら，T. denitrificans には，互いに関連する 2 つの電子 伝達系，または，分岐した電子伝達系が存在する2)とさ れている。T. denitrificans は, 絶対化学独立栄養細菌 (obligate chemoautotrophic bacteria) で, $\mathrm{CO}_{2}$, $\mathrm{HCO}_{3}{ }^{-}, \mathrm{CO}_{3}{ }^{2-}$ などの無機炭素を炭素源として利用し て生育する。

\section{$2.2 T$. denitrificans に利用される還元硫黄化合物}

T. denitrificans は, 前述のように還元硫黄化合物を $\mathrm{O}_{2}$ ，または, $\mathrm{NO}_{3}{ }^{-}$によって $\mathrm{SO}_{4}{ }^{2-}$ に酸化する際に発生 するエネルギーを利用して生育する。硫黄はー 2 か
ら+6の酸化数をとるが, そのらち還元硫黄化合物 は, $-2,0,+2,+4$ の酸化数をもつもので, $\mathrm{S}^{2-}, \mathrm{S}^{0}$, $\mathrm{S}_{2} \mathrm{O}_{3}{ }^{2-}, \mathrm{S}_{4} \mathrm{O}_{6}{ }^{2-}, \mathrm{SO}_{3}{ }^{2-}$ が利用される。T. denitrificans による脱窒反応では，これら還元硫黄化合物は電子供 与体として働くので，酸化数の低い硫黄化合物の方が 脱窒の効率は高くなる。

Bisogni と Driscoll ${ }^{3)}$ は, T. denitrificans の脱窒反応 に和ける硫黄化合物のコストを電子当量当たりの薬品 コストで比較し, 単体硫黄 $\left(\mathrm{S}^{0}\right)$ が最も経済的な電子供 与体であることを明らかにしている。

$\mathrm{S}^{0}$ の特徵として, 資源的に豊富, 安価で, 貯蔵が容易 な上に取り扱い性が良く，毒性がないなどが挙げられ る。 $\mathrm{S}_{2} \mathrm{O}_{3}{ }^{2-}$ は, 溶解度が高い上, 毒性も少なく, 取り 扱い性も良いことから，T. denitrificans による脱窒反 応の電子供与体として多用されてきたが，単位重量当 たりの電子含有量が低い上，高価であることから下廃 水処理に応用する際の電子供与体としては適していな

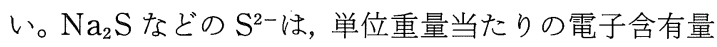
が一番高く, 還元力の強い硫黄化合物であるが, 薬品 としてのコストが $\mathrm{S}^{0}$ に比べて高い上, 毒性, 臭気があ り, 取り扱い性, 貯蔵の容易さなどの点で $\mathrm{S}^{0}$ に劣る。

\section{3. 実験材料および方法}

\section{1 集積培養の方法}

培地 $\mathrm{B}_{1}$ (Table 1 の組成) $50 \mathrm{~m} l$ を，ガス交換装置付 きの $80 \mathrm{~m} l$ 容の L 字管 $(\boldsymbol{F i g} .1$ ) に入れて, これに約 $1 \%$ 容の植種源（大阪府下の污濁河川の底泥，池底泥，下 水処理場の余剰污泥，消化污泥など）を加えて, $30^{\circ} \mathrm{C}$ の熑気条件で振盪培養することにより硫黄脱窒細菌を 集積した。ガス発生と培養液に白濁のみられた試料に ついて，10代までの継代培養を重ねて，脱窒活性の高 い硫黄脱窒細菌の集積をはかった。

\subsection{T. denitrificans の純粋分離法}

集積培養に和いて, 最も生育のよかった培養液を生 理食塩水で希釈し， $2 \%$ 寒天を含む培地 $\mathrm{B}_{1}$ の平板培地 に表面塗抹した後，気相を $\mathrm{N}_{2}$ ガスで置換したデシ ケーター内で, $30^{\circ} \mathrm{C} て ゙$ 培養した。デシケーター内に残 存する微量の酸素は BBL Gas Pak (Becton Dickinson 社製)で完全に除去するとともに, メチレンブルー 指示薬にてデシケーター内部の嫌気度をチェックしな がら培養した。単一コロニーを釣菌後, 同様の手法で 平板培養を 5 回以上繰り返し, 菌の純化をはかった。

\section{3 回分培養試験の方法}

集積培湌液を種污泥とし，ガス交換装置を装着した $500 \mathrm{~m} l$ 容のヒダ付きフラスコ（Fig. 1) に，200〜300 $\mathrm{m} l$ の培地 $\mathrm{B}_{1}$ を入れ，これに約 $5 \%$ 容の前記集積培養 液を加え, $30^{\circ} \mathrm{C}$ の嫌気条件下で振盪培養を行い, 集積 
Table 1 Composition of medium $B_{i}$.

\begin{tabular}{|lr|}
\hline $\mathrm{Na}_{2} \mathrm{~S}_{2} \mathrm{O}_{3} \cdot 5 \mathrm{H}_{2} \mathrm{O}$ & $5.0 \mathrm{~g}$ \\
$\mathrm{KNO}_{3}$ & $2.0 \mathrm{~g}$ \\
$\mathrm{NH}_{4} \mathrm{Cl}$ & $0.5 \mathrm{~g}$ \\
$\mathrm{MgCl}_{2} \cdot 6 \mathrm{H}_{2} \mathrm{O}$ & $0.5 \mathrm{~g}$ \\
$\mathrm{FeSO}_{4} \cdot 7 \mathrm{H}_{2} \mathrm{O}$ & $0.01 \mathrm{~g}$ \\
$\mathrm{NaHCO}_{3}$ & $1.0 \mathrm{~g}$ \\
$\mathrm{KH}_{2} \mathrm{PO}_{4}$ & $2.0 \mathrm{~g}$ \\
Trace metal solution & $40 \mathrm{~m} l$ \\
(see Table 2) & \\
Tap water & $1.0 l$ \\
\hline
\end{tabular}

$* \mathrm{pH}$ was adjusted to 7.0 by $1.0 \mathrm{~N}$ of $\mathrm{NaOH}$.

** Medium which lacks trace metal solution was termed medium B.

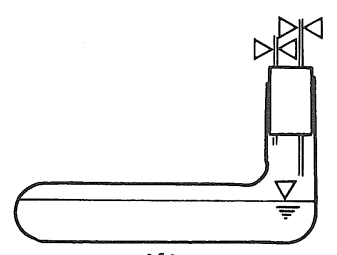

(I)

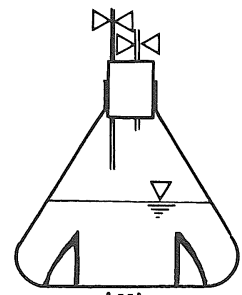

(II)
Fig. 1 Culture vessels.

(I) L shape tube $(80 \mathrm{~m} l)$

(II) Myerflask with baffle $(500 \mathrm{~m} l)$

培養菌の増殖に及ぼす培地成分の影響を検討した。ま た，集積培養菌の回分培養特性は，Fig.2 の回分培養 装置を用いて水温 $28^{\circ} \mathrm{C} て ゙$ 調べた。

\section{4 集積培養菌の $\mathrm{S}^{0}$ 馴養方法}

適量の $\mathrm{Na}_{2} \mathrm{~S}_{2} \mathrm{O}_{3}$ を添加した培地 S (Table 3) 飞 $\mathrm{Na}_{2}$ $\mathrm{S}_{2} \mathrm{O}_{3}$ 添加培地 $\mathrm{B}_{1}$ による集積菌を懸濁させ, Fig. 2 の培 養装置を用いて $28^{\circ} \mathrm{C} て ゙$ 分培養した。

$\mathrm{NO}_{3}-\mathrm{N}$ が消費され，ガス発生が停止した段階で培 地に補填する $\mathrm{KNO}_{3}$ と $\mathrm{Na}_{2} \mathrm{~S}_{2} \mathrm{O}_{3}$ の量を調製して, 培地 中の $\mathrm{S}_{2} \mathrm{O}_{3}-\mathrm{S} / \mathrm{S}^{0}$ 比抒よび $\mathrm{S}_{2} \mathrm{O}_{3}-\mathrm{S} / \mathrm{NO}_{3}-\mathrm{N}$ 比を段階的 に低下させながら回分培養を 9 回繰り返し，集積菌を $\mathrm{S}^{0}$ に馴養させた。な挹, $\mathrm{S}^{0}$ は市販の硫黄を粉砕し, 粒径 をフルイで74 105 $\mu \mathrm{m}$ に調整して使用した。

\section{5 分析方法}

培養混合液を遠心分離 $(5,000 \mathrm{rpm}, 15$ 分間) して， 上澄液と沈殿物に分け, 上澄液については $\mathrm{NH}_{4}-\mathrm{N}$, $\mathrm{NO}_{2}-\mathrm{N}, \mathrm{NO}_{3}-\mathrm{N}, \mathrm{S}_{2} \mathrm{O}_{3}{ }^{2-}, \mathrm{SO}_{4}{ }^{2-}, \mathrm{pH}$ 括よびアルカ リ度を測定した。 $\mathrm{NH}_{4}-\mathrm{N}, \mathrm{NO}_{3}-\mathrm{N}$ はコーンウェイ微 量拡散法4)で, その他の項目は下水試験方法汭炕りそ れぞれ分析した。培養混合液中の $\mathrm{S}^{0}$ 濃度は, $\mathrm{S}^{0}$ を $\mathrm{Na}_{2}$
Table 2 Composition of trace metal solution.

\begin{tabular}{|lr|}
\hline EDTA & $500.0 \mathrm{mg}$ \\
$\mathrm{CaCl}_{2}$ & $55.4 \mathrm{mg}$ \\
$\mathrm{CuSO}_{4} \cdot 5 \mathrm{H}_{2} \mathrm{O}$ & $15.7 \mathrm{mg}$ \\
$\mathrm{CoCl}_{2} \cdot 6 \mathrm{H}_{2} \mathrm{O}$ & $16.1 \mathrm{mg}$ \\
$\mathrm{MnCl}_{2} \cdot 4 \mathrm{H}_{2} \mathrm{O}$ & $50.6 \mathrm{mg}$ \\
$\mathrm{ZnSO}_{4} \cdot 7 \mathrm{H}_{2} \mathrm{O}$ & $220.0 \mathrm{mg}$ \\
$\left(\mathrm{NH}_{4}\right)_{6} \mathrm{Mo}_{7} \mathrm{O}_{24} \cdot 4 \mathrm{H}_{2} \mathrm{O}$ & $11.0 \mathrm{mg}$ \\
$\mathrm{FeSO}_{4} \cdot 7 \mathrm{H}_{2} \mathrm{O}$ & $49.9 \mathrm{mg}$ \\
Deionized water & $1.0 l$ \\
\hline
\end{tabular}

* pH was adjusted to 7.0 by $1.0 \mathrm{~N}$ of $\mathrm{NaOH}$.

Table 3 Composition of medium S.

\begin{tabular}{|c|c|}
\hline $\mathrm{S}^{\circ}$ & $5.0 \mathrm{~g}$ \\
\hline $\mathrm{KNO}_{3}$ & $0.722 \mathrm{~g}$ \\
\hline $\mathrm{NH}_{4} \mathrm{Cl}$ & $0.5 \mathrm{~g}$ \\
\hline $\mathrm{MgCl}_{2} \cdot 6 \mathrm{H}_{2} \mathrm{O}$ & $0.5 \mathrm{~g}$ \\
\hline $\mathrm{FeSO}_{4} \cdot 7 \mathrm{H}_{2} \mathrm{O}$ & $0.01 \mathrm{~g}$ \\
\hline $\mathrm{NaHCO}_{3}$ & $1.0 \mathrm{~g}$ \\
\hline $\mathrm{KH}_{2} \mathrm{PO}_{4}$ & 2.0 \\
\hline $\begin{array}{l}\text { Trace metal solution } \\
\text { (see Table } 2 \text { ) }\end{array}$ & $40 \mathrm{~m} l$ \\
\hline Tap water & 1.0 \\
\hline
\end{tabular}

* pH was adjusted to 6.0 by $0.1 \mathrm{~N}$ of $\mathrm{KOH}$.

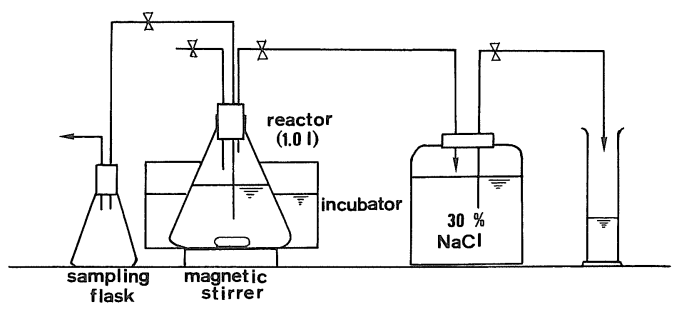

Fig. 2 Experimental setup for batch denitrification experiment.

$\mathrm{SO}_{3}$ で $\mathrm{S}_{2} \mathrm{O}_{3}{ }^{2-}$ 亿変光た後, ヨウ素滴定法6)で分析した。 また, $\mathrm{OD}_{650}$ の吸光度測定では菌体と $\mathrm{S}^{0}$ の別がつか ない恐れがあるため, 遠心分離後の沈殿物を超音波破 砕機で処理し, その TOC 濃度から菌体濃度を評価し た。

\section{4. 実験成績ならびに考察}

\subsection{T. denitrificans の純粋分離}

集積培養液を寒天平板培地に塗抹後, 完全嫌気条件 下のデシケーター中で培養を行ったところ, 約 1 週間 で白色を帯びたコロニーが発生した。このコロニーは, その後培養を続けるにつれ白色から黄色に変化した。 このようにコロニーの色が黄変するのは, 細胞内に硫 黄塊が蓄積したことを示している。 $\mathrm{S}_{2} \mathrm{O}_{3}{ }^{2-を}$ 硫黄源と 
して培養した際に細胞内に蓄積される硫黄塊は, $\mathrm{S}_{2}$ $\mathrm{O}_{3}{ }^{2-}$ とその酸化中間体である polythionate との純粋 な化学反応により生成すると考光られている7)。この 黄変したコロニーを生理食塩水で希釈後, 再び平板培 養して単一コロニーを得た。この操作を 7 回繰り返す ことにより純粋分離株を得た。

この分離株の菌学的諸性質を検討し, Table 4 の結 果を得た。また，Fig。3 には，分離株の生理特性を調 べるために行った試験成績の一例を示した。ここで, 前培養は嫌気条件下で培地 $\mathrm{B}_{1}$ にて行い，これを同じ培 地と $\mathrm{Na}_{2} \mathrm{~S}_{2} \mathrm{O}_{3}$ をグルコースに置き換えた無機塩培地 に植種し培養した。培地 $\mathrm{B}_{1}$ を用いて好気条件で培養す ると, 分離株は 100 時間もの長いラグ期の後, ゆっくり と生育を始めたが，嫌気条件では，50時間のラグ期の 後急速に増殖した。このことは，T. denitrificans は硫 黄酸化の最終電子受容体として, $\mathrm{O}_{2}$ と $\mathrm{NO}_{3}$-の両者を 利用することができるが，本実験のように培養条件を 嫌気から好気に变光た場合, 最終電子受容体が $\mathrm{NO}_{3}{ }^{-}$ から $\mathrm{O}_{2}$ に変換するのに, かなりの時間がかかることを 意味している。また，T. denitrificans の脱窒活性は, 好気状態で植兄継ざを繰り返した場合消失した例7も あることから，分離株は嫌気条件で保存する必要があ る。一方, Fig.3から明らかなように, 分離株はグル コース培地では全く生育することができなかった。ま た，普通寒天培地でも生育できなかったので，通性嫌 気性の自栄養細菌であると判定した。

以上, 分離株の菌学的諸性質をもとに, Bergey's Manual 第 8 版 ${ }^{8)}$ から, 分離株を $T$. denitrificans と同 定した。次に，分離株 $T$. denitrificans を培地 $\mathrm{B}_{1}$ で振 盪培養し, その生育, 脱窒挙動を調べたところ, 200 $\mathrm{mg} \cdot l^{-1}$ の $\mathrm{NO}_{3}-\mathrm{N}$ を完全に脱窒するのに150時間も要 した。これは 50 時間もの長いラグ期による。そこで, 培地 $\mathrm{B}_{1}$ に酵母エキスを $0.1 \%$ 添加して同様に振盪培養 したところ，0.1\%の酵母ェキス添加により，ラグ期な しに $T$. denitrificans の生育と脱窒反応が起こり, 対 数増殖期の比増殖速度も高くなった。その結果, 200 $\mathrm{mg} ・ l^{-1}$ の $\mathrm{NO}_{3}-\mathrm{N}$ を完全に脱窒するのに要する時間 も33時間と大幅に減少した。

Table 4 Bacteriological properties of isolated strain.

\begin{tabular}{|ll|}
\hline Shape & short-rod \\
Motility & $(+)$ \\
Gram staining & negative \\
Strict autotrophic & \\
Facultative anaerobic & \\
Elemental sulfur is oxidized, but its oxydation & rate is slowly than that of $\mathrm{S}_{2} \mathrm{O}_{3}{ }^{2-}$. \\
\hline
\end{tabular}

以上のように, T. denitrificans の分離株について, その生理的諸性質拉よび脱窒能力を種々検討し, 硫黄 脱窒が下廃水処理に適用可能であることが明らかと なった。しかし，本菌は非凝集性で，乙かも，培養生 理特性が極めて特異的であることから，これを下廃水 処理に扔いて純粋な状態で用いることは難しいと判断 された。そこで, 硫黄脱窒細菌の下廃水処理での実用 化のため，純粋菌にこだわらず，広く自然界から硫黄 脱窒能の高い混合菌を集積し，さらに集積菌の単体硫 黄 $\left(\mathrm{S}^{0}\right)$ への馴養について種々検討を加光た。

\section{2 硫黄脱窒細菌の集積培養}

今回, 9 種類の植種源から硫黄脱窒細菌の集積を 図ったが，すべての植種源からガス発生と培養液の白 濁を認めた。ガス発生が終了するのに要した培養日数 は，1代目が11日間であったのに対し， 2 代目， 3 代 目がともに 5 日間と大幅に短縮された。活性の高い硫 黄脱窒細菌を集積するには, 電子供与体としての $\mathrm{Na}_{2}$ $\mathrm{S}_{2} \mathrm{O}_{3}$ 濃度, 無機炭素濃度, それに微量元素濃度によっ て硫黄脱窒細菌の生育が律速を受けないような最適な 培地を使用する必要がある。そこで, S 都市下水処理場 の余剰污泥を植種源として 3 代植光継いだ集積菌を用 いて，その比増殖速度 $(\mu)$ に及ぼす培地成分の影響を 検討した。

Fig. 4 に，集積培養菌の $\mathrm{OD}_{650}$ と菌体 TOC 濃度の 関係を示した。両者の間には極めて高い相関関係が存 在したので, ここでは $\mathrm{OD}_{650}$ の経時変化の直線部傾き をもとに, 集積菌の比増殖速度 $(\mu)$ を求めた。

Table 5 に各種培地成分での比増殖速度 $(\mu)$ を一括 表示した。表示したように, 微量金属成分の添加によっ て $\mu$ が増加したことから，すべての植種源の 4 代目以

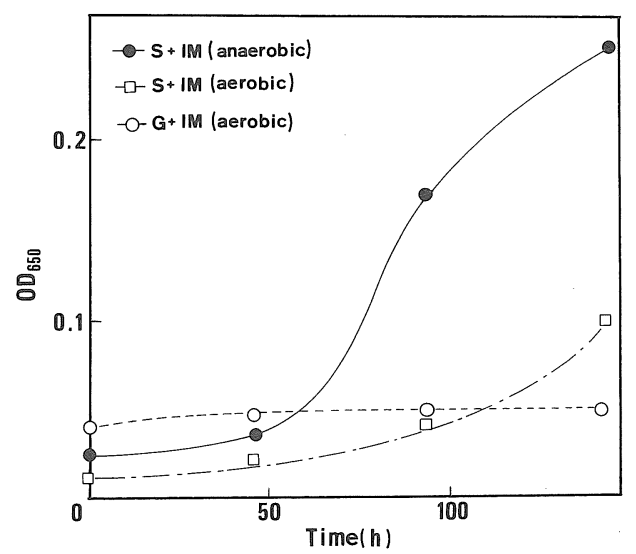

Fig. 3 Growth curves of isolated strain under various cultivating conditions.

* S ; sulfur, G; glucose, IM ; inorganic medium. 
降の培地に, Table 2 に示す組成の微量金属成分濃度 を25倍希釈して培地 B に加えた培地 $\mathrm{B}_{1}$ (Table 1 )を 使用した。次に, $\mathrm{S}$ 都市下水処理場の余唾污泥を植種源 として，8 代，9 代植え継いだ集積菌を用いて， $\mu$ 值に 及ぼす培地の $\mathrm{S}_{2} \mathrm{O}_{3}-\mathrm{S} / \mathrm{NO}_{3}-\mathrm{N}$ 比, アルカリ度 $/ \mathrm{NO}_{3}$ - $\mathrm{N}$ 比の影響を検討した。この時, Table 1 に示したよ らに, 培地 $\mathrm{B}_{1}(\mathrm{pH}=7.0)$ は, リン酸バッファーを含 むため, 培養液の $\mathrm{pH}$ 変化は小さく, 培養終了時の培養 液 $\mathrm{pH}$ は6.5〜7.0であった。ただし, $\mathrm{S}_{2} \mathrm{O}_{3}-\mathrm{S} / \mathrm{NO}_{3}-\mathrm{N}$ を6.0以上とした時，培養液 $\mathrm{pH}$ は6.1まで低下した。

Table 5 に示すように, 培地の $\mathrm{S}_{2} \mathrm{O}_{3}-\mathrm{S} / \mathrm{NO}_{3}-\mathrm{N}$ 比が 4.2 以上, アルカリ度 $/ \mathrm{NO}_{3}-\mathrm{N}$ 比が 2.9 以上であれば, これら培地成分によって硫黄脱窒細菌の増殖が律速を 受けないことがわかった。以上のことから，硫黄脱窒 細菌の自然界からの集積培養の培地としては, Baalsrud・Baalsrud ${ }^{7}$ の培地に微量金属成分を加えた培地 $\mathrm{B}_{1}$ が最適であることが明らかとなった。

継代培養を重ねるごとに，ガス発生終了までの培養 日数は短くなり，5代目では培養 2 日間で， 8 代目か らは培養 1 日でガス発生は終了し, 硫黄脱窒細菌の集

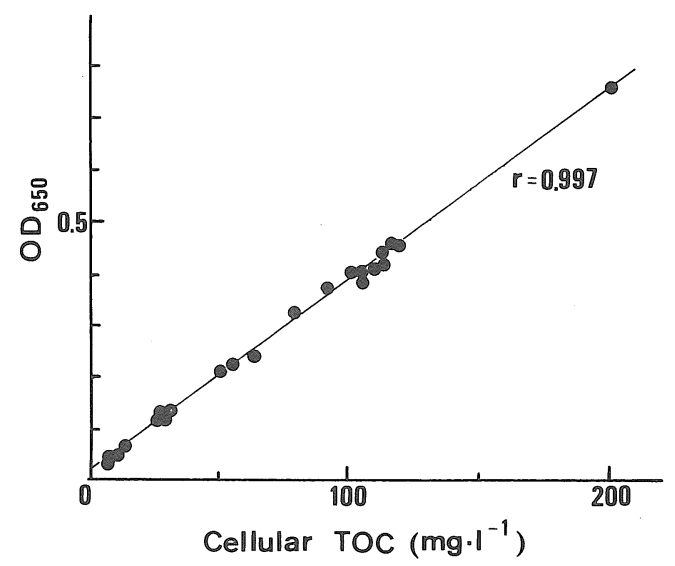

Fig. 4 Relationship between $\mathrm{OD}_{650}$ and the cellular TOC concentration for enrichment culture.
積効果が認められた。9 種類の植種源のうち生育の良 かった O 大学構内雨水沈殿池底泥(2), 寝屋川底泥(4), $\mathrm{S}$ 都市下水処理場混合生污泥(7), 同余剰污泥(8)を植種 源として，10代植え継いだ集積菌の回分脱窒試験成績 を Fig.5に示した。培養24時間後には，いずれの集積 培養菌も95\%以上の脱窒率を示した。培養終了時の培 養液 $\mathrm{pH}$ はいずれも6.7であった。また，L字管を用い た集積培養試験では，いずれの植種源を用いた場合で も, ガス発生量や菌の増殖に伴う培養液の白濁の度合 いが同程度であったことから，自栄養性の硫黄脱窒細 菌は都市域に执いて広く分布していることが確認され た。

集積培養菌は，ラグ期なしに植え継ぎ直後から対数 増殖するので, 対数増殖期の部分をとって解析すると 以下のようになる。対数増殖では次式が成立する。

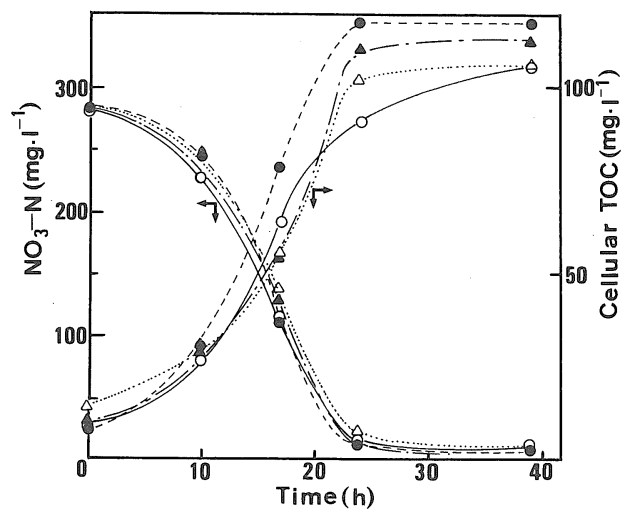

Fig. 5 Sulfur denitrification by various batch enrichment cultures vs. time.

- $\bigcirc$ - bottom mud of sedimentation tank of Osaka University

- - bottom mud of Neya river

$-\triangle-$ activated sludge of domestic wastewater treatment plant

$-\Delta-$ excess sludge of domestic wastewater treatment plant

Table 5 Effect of medium composition on the growth of sulfur denitrifier.

\begin{tabular}{|c|c|c|c|c|c|c|}
\hline Factor & $\begin{array}{l}\begin{array}{l}\text { Seed } \\
\text { culture* }\end{array} \\
\end{array}$ & $\begin{array}{c}\mathrm{S} / \mathrm{N} \text { ratio } \\
\left(\mathrm{mg} \mathrm{S}_{2} \mathrm{O}_{3}{ }^{2-}-\mathrm{S} \cdot \mathrm{mg}^{-1} \mathrm{~N}\right)\end{array}$ & $\begin{array}{c}\text { Alkalinity } / \mathrm{N} \text { ratio } \\
\left(\mathrm{mg} \text { alkalinity } \cdot \mathrm{mg}^{-1} \mathrm{~N}\right)\end{array}$ & $\begin{array}{c}\mathrm{NO}_{3}-\mathrm{N} \\
\left(\mathrm{mg} \cdot l^{-1}\right) \\
\end{array}$ & $\begin{array}{c}\text { Trace metal conc. } \\
\text { (see Table } 2)\end{array}$ & $\begin{array}{l}\text { Specific growth } \\
\text { rate }(\mu)\left(\mathrm{d}^{-1}\right)\end{array}$ \\
\hline $\begin{array}{l}\text { Trace metal } \\
\text { concentration }\end{array}$ & 3 rd & 4.6 & 2.6 & 270 & $\begin{array}{c}\text { no addition } \\
100 \text { times dilution } \\
25 \text { times dilution } \\
5 \text { times dilution }\end{array}$ & $\begin{array}{l}1.4 \\
1.7 \\
1.7 \\
1.8\end{array}$ \\
\hline $\mathrm{S} / \mathrm{N}$ ratio & 8th & $\begin{array}{l}3.2 \\
4.2 \\
6.0 \\
6.6\end{array}$ & 2.6 & 272 & 25 times dilution & $\begin{array}{l}2.1 \\
2.6 \\
2.5 \\
2.3\end{array}$ \\
\hline $\begin{array}{l}\text { Alkalinity } / \mathrm{N} \\
\text { ratio }\end{array}$ & 9th & 4.6 & $\begin{array}{l}2.9 \\
4.6\end{array}$ & 420 & 25 times dilution & $\begin{array}{l}3.2 \\
3.0\end{array}$ \\
\hline
\end{tabular}

* Numbers indicate the transfer number of enriched culture. 
$X=X_{o} \bullet e^{\mu}$

ここで, $X$ : 菌体 TOC 濃度 $\left(\mathrm{mg} \cdot l^{-1}\right)$

$X_{0}:$ 初期菌体 TOC 濃度 $\left(\mathrm{mg} \cdot l^{-1}\right)$

$\mu \quad:$ 比増殖速度 $\left(\mathrm{d}^{-1}\right)$

(1)式の両片の対数をとり, $\ln \left(X / X_{o}\right)$ 飞対し, 培養時 間 $t$ をプロットすると直線が得られ，直線の傾きから $\mu$ が求まる。このようにして求めた対数増殖期に括け る $\mu$ をig. 6 に示した。

比増殖速度 $(\mu)$ は, 寝屋川底泥を植種源とした集積 培養菌が最も高い值となったが，植種源による大さな 差異はみられなかった。

\section{3 集積培養菌による脱窒反応の化学量論}

$\mathrm{S}_{2} \mathrm{O}_{3}{ }^{2-を}$ 電子供与体とする硫黄脱窒反応の化学量 論式は, Bisogni と Driscollis)が energetics 法により次 式のように決定した。

$$
\begin{gathered}
0.844 \mathrm{~S}_{2} \mathrm{O}_{3}{ }^{2-}+\mathrm{NO}_{3}{ }^{-}+0.347 \mathrm{CO}_{2}+0.0865 \mathrm{HCO}_{3}{ }^{-} \\
+0.0865 \mathrm{NH}_{4}{ }^{+}+0.434 \mathrm{H}_{2} \mathrm{O} \longrightarrow 0.0865 \mathrm{C}_{5} \mathrm{H}_{7} \mathrm{O}_{2} \mathrm{~N} \\
+0.5 \mathrm{~N}_{2}+1.689 \mathrm{SO}_{4}{ }^{2-}+0.697 \mathrm{H}^{+} \cdots \cdots \cdot(2)
\end{gathered}
$$

(2)式に基づいて計算した $\mathrm{S}_{2} \mathrm{O}_{3}{ }^{2-を}$ 電子供与体とす る硫黄脱窒反応の化学量論值, $Y_{S}$ (単位除去 $\mathrm{NO}_{3}-\mathrm{N}$ 量当たりの消費 $\mathrm{S}_{2} \mathrm{O}_{3}{ }^{-}-\mathrm{S}$ 量), $Y_{a l k}$ (単位除去 $\mathrm{NO}_{3}-\mathrm{N}$ 量当たりの消費アルカリ度量）执よび $C_{R}$ (消費比 ${ }^{3)}$ : 還元除去される $\mathrm{NO}_{3}$-の単位電子当量当たり消費され る $\mathrm{S}_{2} \mathrm{O}_{3}{ }^{2-}$ の電子当量) の理論值と, 集積培養菌の回分 培養によって得られた実験値の比較を, Fig. 7 Fig. 9

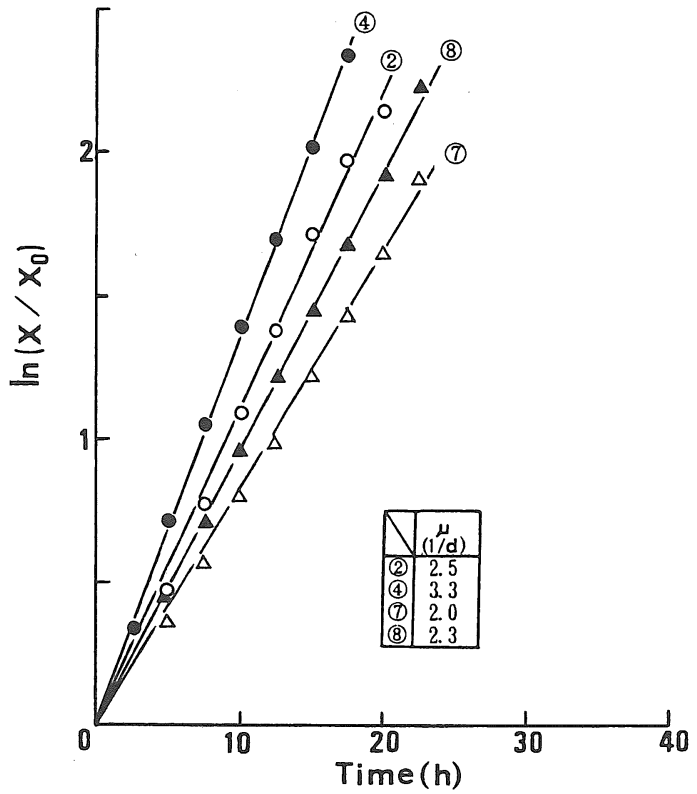

Fig. 6 Relationship between $\ln \left(X / X_{o}\right)$ and time. Numbers in figure indicate the number of inoculating source
にそれぞれ示した。なお，Fig. 9 の横軸 $C_{F}$ 値 ${ }^{3}$ は，培 地中の $\mathrm{NO}_{3}{ }^{-}$の単位電子当量当たりの $\mathrm{S}_{2} \mathrm{O}_{3}{ }^{2-}$ の電子 当量を示す。

$Y_{s}$ の実測平均值は, $3.67 \mathrm{mgS}_{2} \mathrm{O}_{3}-\mathrm{S} \cdot \mathrm{mg}^{-1} \mathrm{NO}_{3}-\mathrm{N}$ で 理論値 $3.86 \mathrm{mgS}_{2} \mathrm{O}_{3}-\mathrm{S} \cdot \mathrm{mg}^{-1} \mathrm{NO}_{3}-\mathrm{N}$ より若干低い值 となり，また， $Y_{a l k}$ の実測平均值も1.96mg アルカリ 度・ $\mathrm{mg}^{-1} \mathrm{NO}_{3}-\mathrm{N}$ と理論值の $2.49 \mathrm{mg}$ アルカリ度・ $\mathrm{mg}^{-1}$ $\mathrm{NO}_{3}-\mathrm{N}$ より低い值となった。 $\mathrm{C}_{R}$ 值も同様に実測平均 值の方が理論値より低くなった。これは，供試集積培 養菌が純粋菌でないことから, 集積培養菌中にいくら かの他栄養脱窒細菌が存在していたためと考兄られ る。しかし， $Y_{s}, Y_{a l k}, C_{R}$ の各化学量論値の実測值が

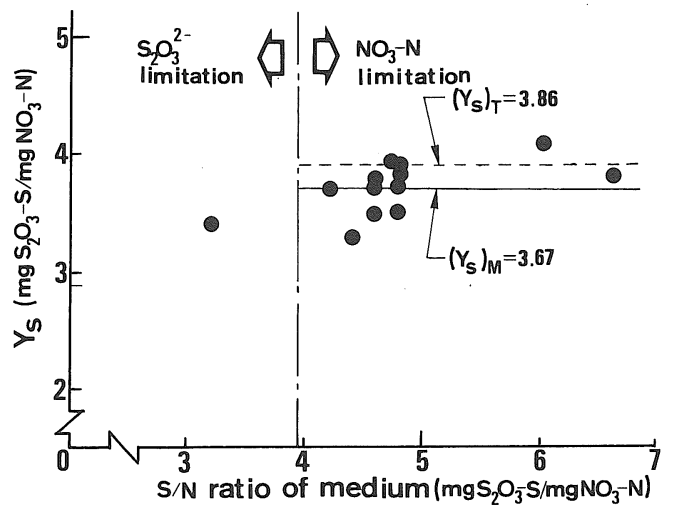

Fig. 7 Relationship between $\mathrm{S} / \mathrm{N}$ ratio of the medium and $Y_{s}$ value for enrichment culture of sulfur denitrifier

$\left(Y_{s}\right)_{T}$ is the theoretical value of $Y_{s}$.

$\left(Y_{s}\right)_{M}$ is the measured value of $Y_{s}$.

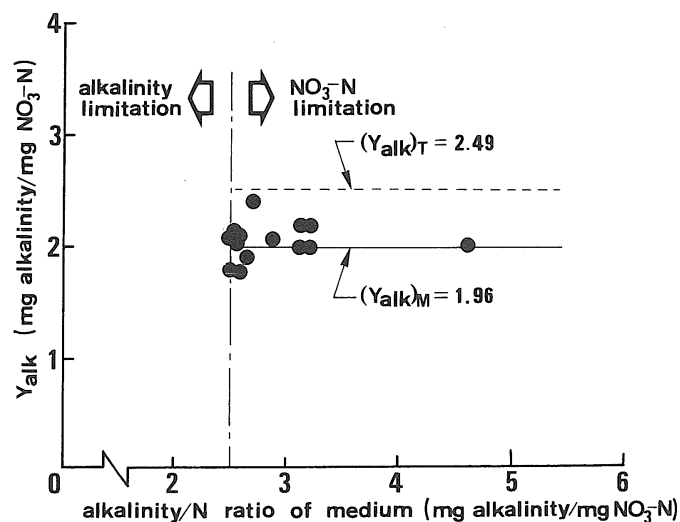

Fig. 8 Relationship between alkalinity/S ratio of the medium and $Y_{\text {alk }}$ value for enriched sulfur denitrifier.

$\left(Y_{a l k}\right)_{T}$ is the theoretical value of $Y_{\text {alk. }}$. $\left(Y_{a l k}\right)_{M}$ is the measured value of $Y_{a l k}$. 


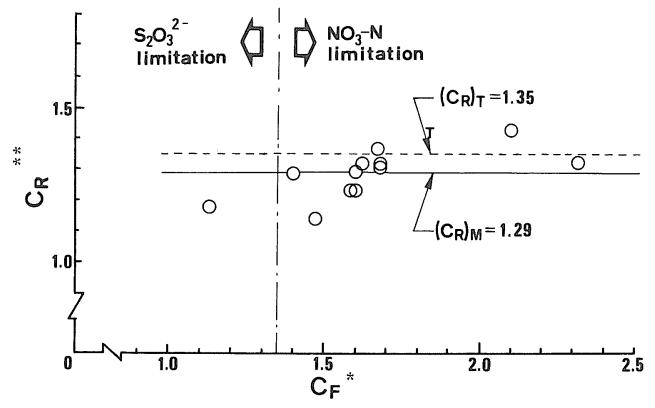

Fig. 9 Relationship between $C_{R}$ value and $C_{F}$ value for the sulfur denitrifier in enriched culture.

* Feed ratio $\left(C_{F}\right)$ is defined as the ratio of electron equivalents of $\mathrm{S}_{2} \mathrm{O}_{3}{ }^{2-}$ in the medium to electron equivalents of $\mathrm{NO}_{3}{ }^{-}$in the medium.

* Consumptive ratio $\left(C_{R}\right)$ is defined as the ratio of electron equivalents of $\mathrm{S}_{2} \mathrm{O}_{3}{ }^{2-}$ consumed to electron equivalents of $\mathrm{NO}_{3}{ }^{-}$reduced.

$\left(C_{R}\right)_{T}$ is the theoretical value of $C_{R}$.

$\left(C_{R}\right)_{M}$ is the measured value of $C_{R}$.

理論值に近い值になったことは，集積培養菌の脱窒能 の汪とんどが硫黄脱窒細菌に依存していることを示唆 している。

次に, 集積硫黄脱窒細菌を用い, $\mathrm{S}_{2} \mathrm{O}_{3}{ }^{2-}$ を硫黄源と した場合の, 回分培養に括ける脱窒の経時変化の一例 を Fig.10に示した。これは, 前述の集積培養に扣いて 強い脱窒活性を示した大学構内雨水沈殿池底泥, 寝屋 川底泥, それに S 都市下水処理場混合生污泥を植種源 として得られた各々の 10 代目の集積菌を等量ずつ混合 した後, 遠心分離 $(5,000 \mathrm{rpm}, 15$ 分間) により濃縮し て, 初発菌体 TOC 濃度を約 $110 \mathrm{mg} \cdot l^{-1}$ とした実験結 果である。 $250 \mathrm{mg} \cdot l^{-1}$ の $\mathrm{NO}_{3}-\mathrm{N}$ が 4 時間培養で直線 的に脱窒除去され, これに対応して, ガス発生量もほ ぼ直線的に増加した。また, $\mathrm{NO}_{3}-\mathrm{N}$ 濃度の減少に伴 い, $\mathrm{S}_{2} \mathrm{O}_{3}-\mathrm{S}$ 濃度も直線的に減少していることは, 培養 期間中一定の $Y_{s}$ 值を保って脱窒反応が進行したこと を示唆している。ここで, 本回分培養での $Y_{s}$ 值は3.39 $\mathrm{mgS}_{2} \mathrm{O}_{3}-\mathrm{S} ・ \mathrm{mg}^{-1} \mathrm{NO}_{3}-\mathrm{N}$ であり, 理論 $Y_{s}$ 值の3.86 $\mathrm{mgS} \cdot \mathrm{mg}^{-1} \mathrm{~N}$ よも少し低い。ぬた, 脱窒終了後は, ガス発生, $\mathrm{S}_{2} \mathrm{O}_{3}-\mathrm{S}$ 濃度の減少, 菌体の増殖のいずれも 完全に停止した。 $\mathrm{NO}_{3}-\mathrm{N}$ 減少曲線の直線部の傾きか ら求めた比脱窒速度 $(k)$ は, $9.4 \mathrm{mgNO}_{3}-\mathrm{N}$ ・菌体 $\mathrm{mg}^{-1}$

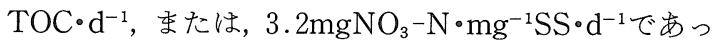
た。な扣，集積培養菌の増殖も培養時間に対し直線的 に増加していることから, $k$ 值を求める際の菌体 TOC 濃度としては, 培養初期值と終了值の平均値を用いた。 また，培養終了時の培養液 $\mathrm{pH}$ は6.6であった。

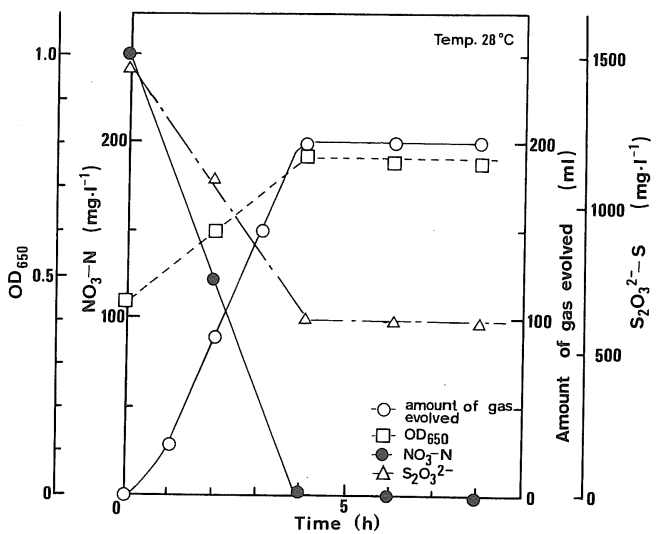

Fig. 10 Denitrification profile of enriched microorganisms by using $\mathrm{S}_{2} \mathrm{O}_{3}{ }^{2-}$ as the reduced sulfur source.

培養終了後，攪拌を停止して，24時間静置し集積培 養菌の沈降性を調べたが, 沈殿する集積菌は非常に少 なく, 集積菌が凝集性に之しく, 固液分離が困難なこ とが判明した。

\section{4 集積培養菌の硫黄馴養経過}

下廃水処理に硫黄脱窒反応を活用する場合, 硫黄源 としては, $\mathrm{S}^{0} か ゙$ 最も経済的である。ここでは, 前述の回 分脱窒試験に用いた混合集積培養菌を, 硫黄源 $\mathrm{S}^{0} に$ 徐々に置換していく方法により $\mathrm{S}^{0} に$ 馴莨させた。 $\mathrm{S}^{0}$ 馴 養過程に拈ける各回分培養（1９回目）のガス発生 量の経時変化を Fig. 11 に示した。

1 回目の回分培養では, 培養 4 時間を境としてガス 発生速度が明らかに低下したが，これは培養 4 時間ま では $\mathrm{S}_{2} \mathrm{O}_{3}{ }^{2-}$ 利用による脱窒であることを示している。 継代培養の 2 回目と 3 回目にも同様の傾向がみられた が，硫黄源が $\mathrm{S}^{0}$ のみとなる継代培養 4 回目と 5 回目に 扣いては，ガス発生量が培養時間に対して直線的に増 加し, しかもその発生速度は馴養を重视るにつれて大 きくなることがわかる。5 回目の継代培養終了後, 培 養混合液を3,000rpm, 30分間の遠心分離で集菌し, 再 び培地の $\mathrm{S}_{2} \mathrm{O}_{3}-\mathrm{S} / \mathrm{NO}_{3}-\mathrm{N}$ 比が2.1となるように $\mathrm{Na}_{2}$ $\mathrm{S}_{2} \mathrm{O}_{3}$ を添加した培地 $\mathrm{S}$ に懸濁させた。次に, 先と同様 に, 培地の $\mathrm{S}_{2} \mathrm{O}_{3}-\mathrm{S} / \mathrm{N}$ 比を徐々に減少させながら 6 回 目から 9 回目の回分培養を行った。

$\mathrm{S}_{2} \mathrm{O}_{3}{ }^{2-}$ と $\mathrm{S}^{0}$ の共存する 6 回目と 7 回目の継代回分 培養に拈いては，1回目から 3 回目でみられた二段階 のガス発生はみられなかったが， $\mathrm{S}_{2} \mathrm{O}_{3}-\mathrm{S} / \mathrm{N}$ 比を減ら すにつれてガス発生速度が低下した。

硫黄脱窒細菌による $\mathrm{S}^{0}, \mathrm{~S}_{2} \mathrm{O}_{3}{ }^{2-}$ の酸化経路について は，多くの研究者により検討されてきたが，現在のと ころ Fig. 12 に示す経路で反応が進行すると考觉られ 


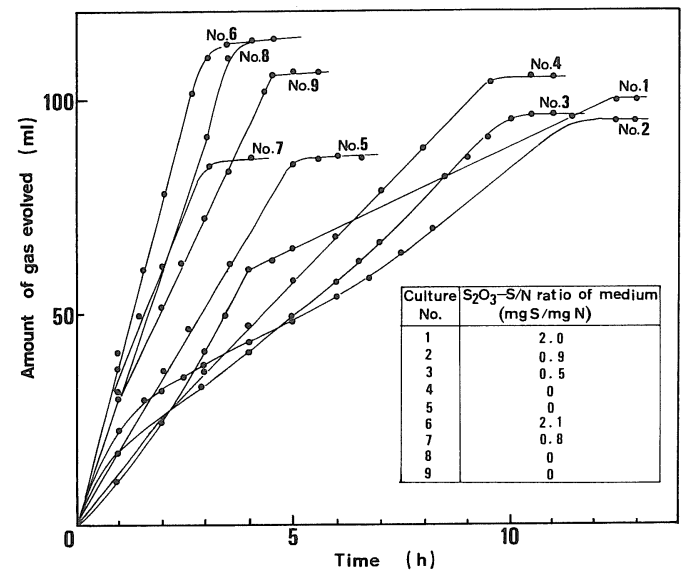

Fig. 11 Gas evolution of each consecutive culture in the acclimation process of enriched sulfur denitrifier vs. time.

* Culture number indicate the consecutive numbers of batch culture in the acclimation process.

ている9,10)。

1 回目から 3 回目の継代培養では, (i)の酵素系を誘 導するのに時間がかかり，二段階のガス発生を示した が，継代培養 6 回目以降の培養では, 集積菌が(i)の酵 素系をすでに完成させていることから, $\mathrm{S}_{2} \mathrm{O}_{3}{ }^{2-}$ 系と $\mathrm{S}^{0}$ 系の両酵素系の作用で脱窒が行われ，その結果， $\mathrm{S}_{2} \mathrm{O}_{3}$ $-\mathrm{S} / \mathrm{NO}_{3}-\mathrm{N}$ 比が高い 6 回目の継代培養が一番高いが ス発生速度を示したと考光られる。 $\mathrm{S}_{2} \mathrm{O}_{3}{ }^{2-}$ 無添加の 8 回目と 9 回目の継代培養でガス発生速度が低下したの は, 反応(i)が反応(iii)より遅いことを示唆している。

Fig. 13 には, $\mathrm{S}^{0}$ 馴養回分培養の進行に伴う化学量論 值 $Y_{s}, Y_{a l k}, Y_{o b s}$ (単位除去 $\mathrm{NO}_{3}-\mathrm{N}$ 量当たりの生成 菌体 $\mathrm{TOC}$ 量)の変化を示した。 $\mathrm{S}^{0}$ 電子供与体とする 硫黄脱窒反応の化学量論式は前述のように次式で示さ れる3)。

$$
\begin{aligned}
& 1.114 \mathrm{~S}^{0}+\mathrm{NO}_{3}{ }^{-}+0.699 \mathrm{H}_{2} \mathrm{O}+0.337 \mathrm{CO}_{2} \\
& +0.0842 \mathrm{HCO}_{3}{ }^{-}+0.0842 \mathrm{NH}_{4}{ }^{+} \longrightarrow 0.0842 \mathrm{C}_{5} \mathrm{H}_{7} \mathrm{O}_{2} \mathrm{~N} \\
& +0.5 \mathrm{~N}_{2}+1.114 \mathrm{SO}_{4}{ }^{2-}+1.228 \mathrm{H}^{+} \ldots \ldots \ldots \cdots \cdots \cdot(3) \\
& \text { (3)式に基ついて算出した硫黄脱窒反応の化学量論值 }
\end{aligned}
$$
と $\mathrm{S}_{2} \mathrm{O}_{3}{ }^{2-を}$ 電子供与体とした場合のそれをTable 6 に示した。両者の化学量論値の差は， $Y_{s}, Y_{a l k}$ で顕著 であるが, $Y_{o b s}, C_{R}$ では差のないことがわかる。 $\mathrm{S}_{2} \mathrm{O}_{3}{ }^{2-}$ 添加量を減らし電子供与体を $\mathrm{S}^{0}$ に変えていくと $Y_{s}$ 值 が低下し，Y $Y_{a l k}$ 值が増加する様子は，Fig.13 から明ら かである。以上より, 硫黄脱窒反応の硫黄源を $\mathrm{S}_{2} \mathrm{O}_{3}{ }^{2-}$ から徐々に $\mathrm{S}^{0}$ に置き換える方法により $\mathrm{S}_{2} \mathrm{O}_{3}{ }^{2-}$ 集積培 養菌を， $\mathrm{S}^{0}$ に馴養させることに成功した。

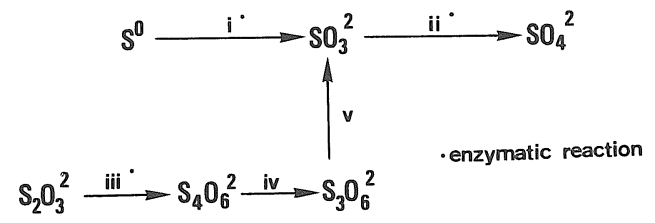

Fig. 12 Oxidative pathway of $\mathrm{S}^{0}$ and $\mathrm{S}_{2} \mathrm{O}_{3}{ }^{2-}$ using sulfur denitrifier ${ }^{9), 10)}$.

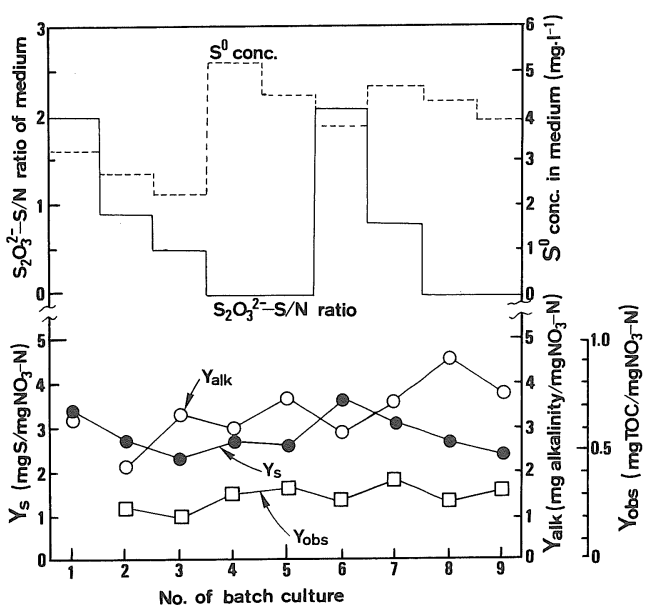

Fig. 13 Changes in stoichiometric values for the batch $\mathrm{S}^{0}$ acclimation cultures.

Fig.14には, S $S^{0}$ 硫黄源とした回分培養の一例とし て, 継代培養 9 回目の脱窒経時変化を示した。Fig.10 に示した $\mathrm{S}_{2} \mathrm{O}_{3}{ }^{2-を}$ 硫黄源とする回分脱窒試験の場合 之同様, $\left(\mathrm{NO}_{3}+\mathrm{NO}_{2}\right)-\mathrm{N}$ は直線的に減少したが, $\mathrm{S}^{0}$ を用いた場合，培養の途中で $20 \sim 30 \mathrm{mg} ・ l^{-1}$ の $\mathrm{NO}_{2}-\mathrm{N}$ が検出された。また, 図より比脱窒速度は, $2.5 \mathrm{mgNO}_{3}$ - $\mathrm{N} ・$ 菌体 $\mathrm{mg}^{-1} \mathrm{TOC} \cdot \mathrm{d}^{-1}$ で $\mathrm{S}_{2} \mathrm{O}_{3}{ }^{2-を}$ 用いた場合の $1 / 3$ 以下の低い值となった。 $\mathrm{S}^{0}$ 用いた場合の比脱窒速度 が低くなった理由として，(1) Fig.12の反応(i)より(iii) のほうが速い，(2) $\mathrm{S}_{2} \mathrm{O}_{3}{ }^{2-}$ は溶解度が高く，硫黄脱窒 細菌に利用されやすいのに対し， $\mathrm{S}^{0}$ は水に不溶性で利 用されにくい，(3) $\mathrm{S}^{0}$ を硫黄源とした回分脱窒試験で は, $20 〜 30 \mathrm{mg} ・ l^{-1}$ の $\mathrm{NO}_{2}-\mathrm{N}$ が蓄積したことから，こ の $\mathrm{NO}_{2}$-により硫黄脱窒細菌の $\mathrm{NO}_{3}$-還元酵素系が阻 害された7), などの理由が考兄られる。また, 培養終了 時の培養液 $\mathrm{pH}$ は6.5であった。培養終了後, 24時間静 置して $\mathrm{S}^{0}$ に馴養した集積培養菌が固液分離能を有す るかどらかを検討した。 $\mathrm{S}_{2} \mathrm{O}_{3}{ }^{2-を}$ 用いた回分脱窒試験 の場合と同様に，注とんど沈殿は見られず，硫黄源を かえても集積培養菌は凝集沈殿性を獲得しないことが

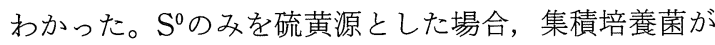
$\mathrm{S}^{0}$ の表面に付着生育して固液分離能を示すことも考光 
Table 6 Theoretical stoichiometric values for sulfur denitrification reaction.

\begin{tabular}{|c|c|c|c|c|}
\hline $\begin{array}{l}\text { Species of reduced } \\
\text { sulfur source }\end{array}$ & $\begin{array}{c}\mathrm{Y}_{\mathrm{s}} \\
\left(\mathrm{mg} \mathrm{S} \cdot \mathrm{mg}^{-1} \mathrm{NO}_{3}-\mathrm{N}\right)\end{array}$ & $\begin{array}{c}\mathrm{Y}_{\mathrm{alk}} \\
\left(\mathrm{mg} \text { alkalinity } \bullet \mathrm{mg}^{-1} \mathrm{NO}_{3}-\mathrm{N}\right)\end{array}$ & $\begin{array}{c}\mathrm{Y}_{\text {obs }} \\
\left(\mathrm{mg} \mathrm{TOC} \cdot \mathrm{mg}^{-1} \mathrm{NO}_{3}-\mathrm{N}\right)\end{array}$ & $\begin{array}{c}\mathrm{C}_{\mathrm{R}} \\
\text { (electron equivalents of reduced sulfur } \\
\left.\text { source/electron equivalents of } \mathrm{NO}_{3}-\mathrm{N}\right)\end{array}$ \\
\hline $\mathrm{S}_{2} \mathrm{O}_{3}{ }^{2-}$ & 3.86 & 2.49 & 0.371 & 1.35 \\
$\mathrm{~S}^{0}$ & 2.55 & 4.39 & 0.361 & 1.34 \\
\hline
\end{tabular}

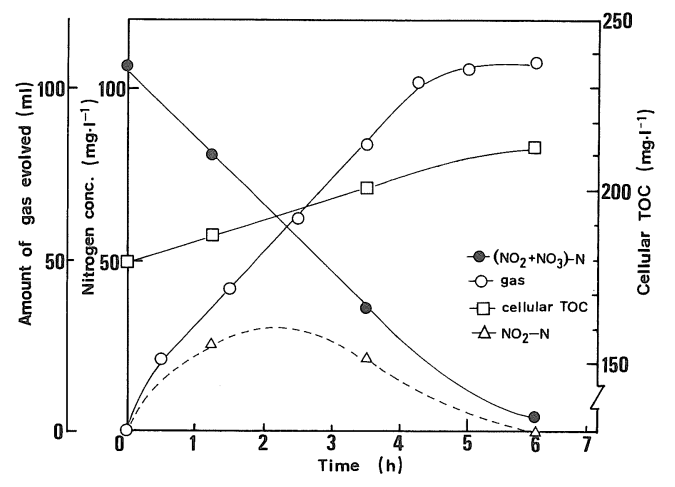

Fig. 14 Batch sulfur denitrification using elemental sulfur as H-donor vs. time.

られるが，顕微鏡観察からはこの点を確認することは できなかった。

\section{5 集積培養菌の脱窒能}

自然界から集積培養法により得た集積硫黄脱窒細菌 の脱窒能と他の脱窒細菌の脱窒能の比較を Table 7 に 示した。本実験で得た集積培養菌の脱窒能は，他栄養 脱窒細菌であるPseudomonas denitrificans の脱窒能 に及ばないものの, 脱窒反応の遅い $\mathrm{S}^{0}$ を硫黄源とした 場合でも, 集積培養菌は $1.3 \mathrm{mgNO}_{3}-\mathrm{N} \cdot \mathrm{mg}^{-1} \mathrm{SS} \cdot \mathrm{d}^{-1}$ の脱窒速度を示し, メタノールを電子供与体とした場 合の活性栃泥の脱窒能に比べて, 高い脱窒能を有する ことが明らかである。回分培養の結果ではあるが，硫 黄脱窒能を有する集積培養菌の脱窒活性はかなり高 く, 他栄養脱窒菌と比肩しらる汪ど高いものである。

\section{5. 要約}

硫黄脱窒細菌の脱窒能を下廃水処理に活用すること を目的として, 硫黄脱窒活性の高い集積菌を $\mathrm{S}_{2} \mathrm{O}_{3}{ }^{2-を}$ 用いて自然界から集積し, 得られた集積菌の脱窒挙動 を回分脱窒試験によって明らかにするとともに，集積 菌の $\mathrm{S}^{0} へ$ 馴養をはかり，次の知見を得た。

1) 完全嫌気条件下で, $\mathrm{S}_{2} \mathrm{O}_{3}{ }^{2-}, \mathrm{HCO}_{3}{ }^{-}, \mathrm{NO}_{3}{ }^{-}, \mathrm{NH}_{4}{ }^{+}$ を含む無機寒天培地上で集積菌の平板培養を行い,

T. denitrificans に特有の硫黄の沈着粒の見られる 黄色コロニーを得た。平板培養を繰り返して得た純 粋菌につき分類試験を行い, 分離菌をT. denitrificans と同定した。

2 ）硫黄脱窒細菌の集積分離用の培地としては, Baalsrud・Baalsrud の培地に微量金属成分を加えた培地 が適していた。

3）下水処理場活性污泥, 污濁河川の底泥などを植種 源に, 炭素源として $\mathrm{HCO}_{3}{ }^{-}$, 硫黄源として $\mathrm{S}_{2} \mathrm{O}_{3}{ }^{2-}$ それぞれ用いた培地により，嫌気条件下で脱窒能の ある菌の集積をはかった結果，すべての植種源から $T$. denitrificans が得られ, 本菌は自然界に普遍的に 存在することがわかった。

4 ) $\mathrm{S}_{2} \mathrm{O}_{3}{ }^{2-を}$ 硫黄源とした場合の, 集積培養菌の硫黄 脱窒反応に関する化学量論值 $\left(Y_{s}, Y_{a l k}, Y_{o b s}, C_{R}\right)$ が理論值にほぼ一致することから，集積培養菌の脱 窒能のほとんどが硫黄脱窒細菌に由来していること がわかった。

5) $\mathrm{S}_{2} \mathrm{O}_{3}{ }^{2-を}$ を硫黄源として集積した硫黄脱窒集積菌 を, 硫黄源を徐々に $\mathrm{S}^{0}$ に置き換える方法により $\mathrm{S}^{0}$ に 馴養させることができた。

Table 7 Comparison of denitrification capabilities for various kinds of denitrifiers.

\begin{tabular}{|c|c|c|c|c|}
\hline $\begin{array}{l}\text { Kinds of } \\
\text { denitrifier }\end{array}$ & $\mathrm{H}$-donor & $\begin{array}{l}\text { Temp. } \\
\left({ }^{\circ} \mathrm{C}\right)\end{array}$ & $\begin{array}{l}\text { Specific denitrification rate } \\
\left(\mathrm{mg} \mathrm{N} \cdot \mathrm{mg}^{-1} \mathrm{SS} \cdot \text { day }\right)\end{array}$ & References \\
\hline $\begin{array}{l}\text { Activated } \\
\text { sludge }\end{array}$ & $\mathrm{CH}_{3} \mathrm{OH}$ & 27 & 0.60 & Michael, R.P. et al..$^{(10)}$ \\
\hline $\begin{array}{l}\text { Pseudomonas } \\
\text { denitrificans }\end{array}$ & $\begin{array}{l}\text { Sodium } \\
\text { Citrate }\end{array}$ & 27 & 4.08 & Dawson, R.N. et al..$^{(11)}$ \\
\hline $\begin{array}{l}\text { Enriched sulfur } \\
\text { denitrifier }\end{array}$ & $\begin{array}{l}\mathrm{Na}_{2} \mathrm{~S}_{2} \mathrm{O}_{3} \\
\mathrm{~S}^{0}\end{array}$ & $\begin{array}{l}28 \\
28\end{array}$ & $\begin{array}{l}3.2 \\
1.32 *\end{array}$ & This work \\
\hline
\end{tabular}

* This value was calculated from the batch denitrification experiment shown in Fig. 13 based on the assumption of cellular composition as $\mathrm{C}_{5} \mathrm{H}_{7} \mathrm{NO}_{2}$. 
6 ）硫黄源として $\mathrm{S}_{2} \mathrm{O}_{3}{ }^{2-}, \mathrm{S}^{0}$ のいずれを用いても集積 培養菌の脱窒反応は 0 次反応火従った。 $\mathrm{S}_{2} \mathrm{O}_{3}{ }^{2-}$ 用 いた場合の集積菌の比脱窒速度は, $9.4 \mathrm{mgNO}_{3}-\mathrm{N} ・$ 菌体 $\mathrm{mg}^{-1} \mathrm{TOC} \cdot \mathrm{d}^{-1}, \mathrm{~S}^{0}$ を用いた場合の比脱窒速度 は，2.5 $\mathrm{mgNO}_{3}-\mathrm{N} ・$ 菌体 $\mathrm{mg}^{-1} \mathrm{TOC} \cdot \mathrm{d}^{-1}$ となり，他 栄養脱窒菌に比肩し得る注ど高い脱窒能であった。

（原稿受理 1989 年 3 月 13 日）

\section{参 考 文 献}

1) Ishaque, M. and Aleem, M.I.H. (1972) Intermediates of Denitrification in Thiobacillus denitrificans, Bacteriol. Proc., 72, 175.

2 ) Peeters, T. and Aleem, M.I.H. (1970) Oxidation of Sulfur Compounds and Electron Transport in Thiobacillus denitrificans, Arch. Mikrobiol., 71, 319-330.

3 ) Bisogni, J.J.Jr. and Driscoll, C.T.Jr. (1977) Denitrification using Thiosulfate and Sulfide, J. Env. Eng., Am. Soc. Civ. Eng., 103, 593-604.
4 ) 土壤盖分測定法委員会編 (1971) 土壤養分分析法, 広川書店.

5 ）下水試験方法一1974年版一-(1974) 日本下水道協会.

6 ) Lawrence, A.W. (1978) Autotrophic Denitrification using Sulfur Electron Donors, U.S. EPA-600/2-78-113.

7 ) Baalsrud, K. and Baalsrud, K.S. (1954) Studies on Thiobacillus denitrificans, Arch. Mikrobiol., 20, 34-62.

8 ) Buchanan, R.E. and Gibbons, N.E. (1974) Bergey's Manual of Determinative Bacteriology, Eighth Edition, The Williams \& Wilkins Company, 456-461.

9 ) 今井和民著 (1984)独立栄養細菌, 化学同人.

10) Vishniac, W. and Santer, M. (1957) The Thiobacilli, Bacteriological Review, 21, 195-213.

11) Michael, R.P. and Jewell, W.J. (1975) Optmization of Denitrification Process, J. Env. Eng., Am. Soc. Civ. Eng., 101, 643-657.

12) Dawson, R.N. and Murphy, K.L. (1972) Factors Affecting Biological Denitrification of Wastewater, Advances Water Pollut. Res., Proceedings 6th Inter. Conference held in Jerusalem, 671-680. 


\section{論文要旨}

\section{燧灘海域の底層環境における酸素消費速度}

星加 章* 谷本 照巳* 川名吉一郎*

* 通産省工業技術院中国工業技術試験所

〈水質污濁研究 Vol.12 No.7 （1989） pp.423 430〉

瀬戸内海の燧灘に扔いて，1986年 9 月拉よび1987年 7 月と 9 月に, ベルジャーシステムを用いて堆積物と直 上水を含む底層環境の酸素消費速度を現位置で測定した。3 回の測定結果の平均酸素消費速度は, 燧灘の中央 部と西部海域でそれぞれ 650 秥よび $410 \mathrm{mg} \cdot \mathrm{m}^{-2} \cdot \mathrm{d}^{-1}$ であった。東部海域では底層水中で光合成が行われている ことが示唆されたため, その影響を補正することにより， $950 \mathrm{mg} \cdot \mathrm{m}^{-2} ・ \mathrm{~d}^{-1}$ 程度と推測された。酸素消費速度 は堆積物中の有機物含有量が高い東部海域で速く, 濃度が低い西部海域で遅い傾向があることを認めた。

\section{硫黄脱窒菌の集積と単体硫黄への馴養}

橋本 奨* 古川 憲治* 塩山 昌彦**

* 大阪大学工学部環境工学科 ** 同 (現在久保田鉄工(株)環境研究部)

〈水質污濁研究 Vol.12 No.7 （1989） pp.431 440〉

Thiobacillus denitlificans の硫黄脱窒能力を下廃水の窒素除去に応用することを最終目的として，自然界か ら T. denitlificans を純粋分離し，その脱窒特性につき検討した。また，硫黄脱窒活性の高い菌の自然界からの 集積と集積菌の単体硫黄 $\left(\mathrm{S}^{0}\right)$ への馴養につき検討した。

無機炭素源として $\mathrm{HCO}_{3}{ }^{-}$, 還元硫黄源として $\mathrm{S}_{2} \mathrm{O}_{3}{ }^{2-}$ を用いた無機合成培地により, 活性污泥, 污濁河川の底 泥などの植種源から，完全嫌気条件下で硫黄脱窒菌の集積培養を行った結果，すべての植種源から硫黄脱窒能 のある集積菌を得ることができた。この集積培養菌を完全嫌気条件下で平板培養することにより，硫黄沈着粒 のみられる黄色の単一コロニーを得た。平板培養を繰り返して得られた純粋菌につき分類試験を行い, 分離菌 をT. denitrificans と同定した。

$\mathrm{S}_{2} \mathrm{O}_{3}{ }^{2-を}$ 還元硫黄源とする集積菌の回分試験成績をもとに硫黄脱窒反応に関する化学量論值 $\left(Y_{\mathrm{S}}, Y_{\mathrm{a} 1 \mathrm{k}}\right.$, $\left.Y_{\mathrm{obs}}, C_{\mathrm{R}}\right)$ を計算した結果から，集積培養菌の脱窒能の涪とんどが硫黄脱窒細菌に由来していることを明らか にした。還元硫黄源を $\mathrm{S}_{2} \mathrm{O}_{3}{ }^{2-}$ から, $\mathrm{S}^{0}$ に徐々に置き換える方法によって, 集積菌が $\mathrm{S}^{0}$ を利用できるよう馴養す ることができた。硫黄脱窒反応は，0 次反応に従い, $\mathrm{S}_{2} \mathrm{O}_{3}{ }^{2-}, \mathrm{S}^{0}$ を脱窒反応の $\mathrm{H}$-donor とした場合の比脱窒速 度は, それぞれ $9.4 \mathrm{mgN} \cdot \mathrm{mg}^{-1} \mathrm{TOC} ・ \mathrm{~d}^{-1}, 2.5 \mathrm{mgN} \cdot \mathrm{mg}^{-1} \mathrm{TOC} \cdot \mathrm{d}^{-1}$ と硫黄脱窒菌は他栄養脱窒菌に劣らぬ 脱窒能を有することがわかった。 